\title{
Theory-Based Interventions in Physical Activity: A Systematic Review of Literature in Iran
}

\author{
Jalal Abdi ${ }^{1}$, Hassan Eftekhar ${ }^{1}$, Fatemeh Estebsari ${ }^{2}$ \& Roya Sadeghi ${ }^{1}$ \\ ${ }^{1}$ Department of Health Education and Promotion, School of public Health, Tehran University of Medical \\ Sciences, Tehran, Iran \\ ${ }^{2}$ School of Public Health, IRAN University of Medical Sciences, Tehran, Iran \\ Correspondence: Hassan Eftekhar, Professor of Health Education, Department of Health Education and \\ Promotion, School of Public Health, Tehran University of Medical Sciences, Tehran, Iran. Tel: 98-21-8895-5888, \\ Fax: 98-21-8898-9129. E-mail: Eftkhara@sina.tums.ac.ir
}

Received: September 29, 2014 Accepted: October 20, 2014 Online Published: November 30, 2014

doi:10.5539/gjhs.v7n3p215 URL: http://dx.doi.org/10.5539/gjhs.v7n3p215

\begin{abstract}
Lack of physical activity is ranked fourth among the causes of human death and chronic diseases. Using models and theories to design, implement, and evaluate the health education and health promotion interventions has many advantages. Using models and theories of physical activity, we decided to systematically study the educational and promotional interventions carried out in Iran from 2003 to 2013.Three information databases were used to systematically select papers using key words including Iranian Magazine Database (MAGIRAN), Iran Medical Library (MEDLIB), and Scientific Information Database (SID). Twenty papers were selected and studied .Having been applied in 9 studies, The Trans Theoretical Model (TTM) was the most widespread model in Iran (PENDER in 3 studies, BASNEF in 2, and the Theory of Planned Behavior in 2 studies). With regards to the educational methods, almost all studies used a combination of methods. The most widely used Integrative educational method was group discussion. Only one integrated study was done. Behavior maintenance was not addressed in $75 \%$ of the studies. Almost all studies used self-reporting instruments. The effectiveness of educational methods was assessed in none of the studies. Most of the included studies had several methodological weaknesses, which hinder the validity and applicability of their results .According to the findings, the necessity of need assessment in using models, epidemiology and methodology consultation, addressing maintenance of physical activity, using other theories and models such as social marketing and social-cognitive theory, and other educational methods like empirical and complementary are suggested.
\end{abstract}

Keywords: health education interventions, Iran, model, physical activity, theory

\section{Introduction}

Physical inactivity is now identified as the fourth leading risk factor for global mortality (World Health Organization [WHO], 2010). Physical inactivity levels are rising in many countries with major implications for the prevalence of non communicable diseases (NCDs) and the general health of the population worldwide, about 3.2 million people die due to lack of physical activity Every year (WHO, 2013, 2010).

With changing social and economic patterns all over the world, sedentary lifestyles have become a worldwide phenomenon (Lee, Macfarlane, Lam, \& Stewart, 2011). This phenomenon is common in teenagers, adults, and elderly people worldwide (Timori \& Esmailnasab, 2011).

Despite all significant effects on human life, technology has increased the tendency to inactive lifestyles (karimi \& Eshrati, 2012). Today, lack of physical activity is considered as one of the most important problems in the field of public health (Solhi, Motlagh, Shirazi, Taghdisi, \& Jalilian, 2012; Tabatabaei, Taghdisi, Sadeghi, \& Nakhaei, 2010).

There is a wide consensus on the benefits of physical activity in health and in disease (Oyeyemi et al., 2011). Regular physical activity has an important role in reducing the risk of diseases such as cardiovascular disease, diabetes, cancer, and in weight management to prevent obesity (Van Wier et al., 2006). Physical activity (PA) reduces the rate of hospitalization, visiting doctors, and the need to take medicine. It can also reduce the rate of absence from work and accordingly increases the productivity and engaging in job. Promoting mental health, 
self-esteem, mood, and reducing the risk of stress and depression are among the benefits of physical activity (WHO, 2013; Pirasteh et al., 2012; Strijk, Proper, van Mechelen, \& van der Beek, 2013).

Physical inactivity is common in Iran, particularly in females and in the older age groups (Esteghamati et al., 2011). Koohpayehzadeh et al. (2014) showed that the overall prevalence of physical inactivity in Iran was increased from $15 \%$ (2007) to $21.5 \%$ (2011) Over the 4 years, $56.4 \%, 39.2 \%$, and $74.4 \%$ of participants were physically inactive at work, commuting and recreation, respectively.

It has been evidently shown that $70-80 \%$ of people in Iran lack enough physical activity (Solhi, Ahmadi, Taghdisi, \& Haghani, 2011; Hashemi, Rakhshani, Navidian, \& Mosavi, 2013) and 65\% of youth are far from reaching the recommended levels of physical activity [i.e., $30 \mathrm{~min}$ of moderate PA per day, five or more days of the week or vigorous PA at least 20 min per day, three or more days a week] (Saffari, Amini, Ardebili, Mahmoudi, \& Sanaeinasab, 2012b).

The world is shifting towards the use of theory- based interventions to increase the level of PA. Glanz and Bishop (2010) stated that, "Increasing evidence suggests that public health and health-promotion interventions that are based on social and behavioral science theories are more effective than those lacking a theoretical base." While little success in changing behavior is documented where no theory was used, theory-based interventions have had significant success in designing effective interventions that are guided by constructs of each theory to change people's behaviors. Theory-based interventions have been associated with larger and longer-term effects than those without an explicit basis in theory (Skaal \& Pengpid, 2012). The most common Theories/models in health education/promotion programs are presented in Appendix A.

Several studies have confirmed the effect of education on changing physical behavior (WHO, 2012; Moeini et al., 2010; Saffari, Shojaeezade, Ghofrani Pour, Heydarnia, \& Pakporhajiagha, 2012a). To improve the effectiveness of health education programs, it is proposed to use patterns and theories. Each model or theory follows a structural sequence of planning, implementation, and evaluation. Applying these models and theories 1: helps to identify the measurable sequences of the program, 2: reveals how behaviors go through changes, 3 : determines the timing of interventions, 4: helps to choose an appropriate combination of strategies, 5: improves the relationship between experts, and 6: improves the programs repetitions and boosts the effectiveness of the program (Saffari et al., 2012a).

In recent years, health education models and theories have been increasingly used in Iran as a framework for designing and implementing interventions. The aim of this review was to critical appraisal of the existing literature reported on the effectiveness of theory-based interventions in physical activity in Iran.

\section{Methods}

\subsection{Search Strategy}

In order to identify studies in which health education and promotion models and theories were applied, three databases including, MAGIRAN, MEDLIB, and SID were searched. These database publish scientific and peer review studies.

Studies available on these websites were selected according to (1) physical activity (2) health behavior change model (3) health education and promotion models (e.g: BASNEF), (4) the aim of the intervention (e.g: identifying the effectiveness of education), and (5) the type of the study (e.g:clinical trial and PRECEDE).

All studies were performed from 2003 to 2013. Before 2003, there were no articles that used health education and promotion models/theories in physical activity.

\subsection{Selecting the Studies}

The title and the abstract of the studies were saved on an electronic database for future references and reference management .all articles were selected by two authors, independent of each other .possible disagreement were resolved by discussion and consensus. After an initial list of included studies was developed, the third author, an expert in health education and health promotion reviewed the list for completeness.

\subsection{Inclusion Criteria}

In order for a study to be selected, 5 criteria were defined:

Studies that used health education and promotion models and theories.

Studies that aimed to investigate the effect of education using theories and models.

Studies that were experimental or a quasi- experimental. 
Studies that yielded physical activity as one of its main outcomes.

Studies that were published in Persian.

No limits were considered for the type of intervention, the duration of intervention, and follow-up activities. (Flow chart1)

\subsection{Exclusion Criteria}

Studies that were descriptive and cross-sectional.

Studies that used health education and promotion models/theories to simply investigate effective factors and determinants in physical activity.

\subsection{Data Collection, Data Analysis, and Classification}

To collect required data, 1) selected studies were scrutinized(rough plan, the duration of the study, etc.), 2) the features of the population were evaluated(job characteristics, etc.) and 3) the focus of the study (physical activity promotion), and 4) the way of measuring outcomes were studied (self reporting, using the instruments, etc.).

\subsection{Quality Assessment Tool}

We adapted methodological quality assessment for the included studies from CONSORT (Brooks, Higgins \& Webster, 2010) and Chen et al's check list(2014).A total Methodological quality score was calculated by summing up all "yes" studies that met $70 \%$ of the criteria,were rated as having high methodological quality (Table 3).

\section{0 papers were excluded:}

142 papers dealt with issues rather than physical activity.

10 descriptive studies were performed on physical activity using the models.

8 papers focused on the effective factors on physical activity using the models.
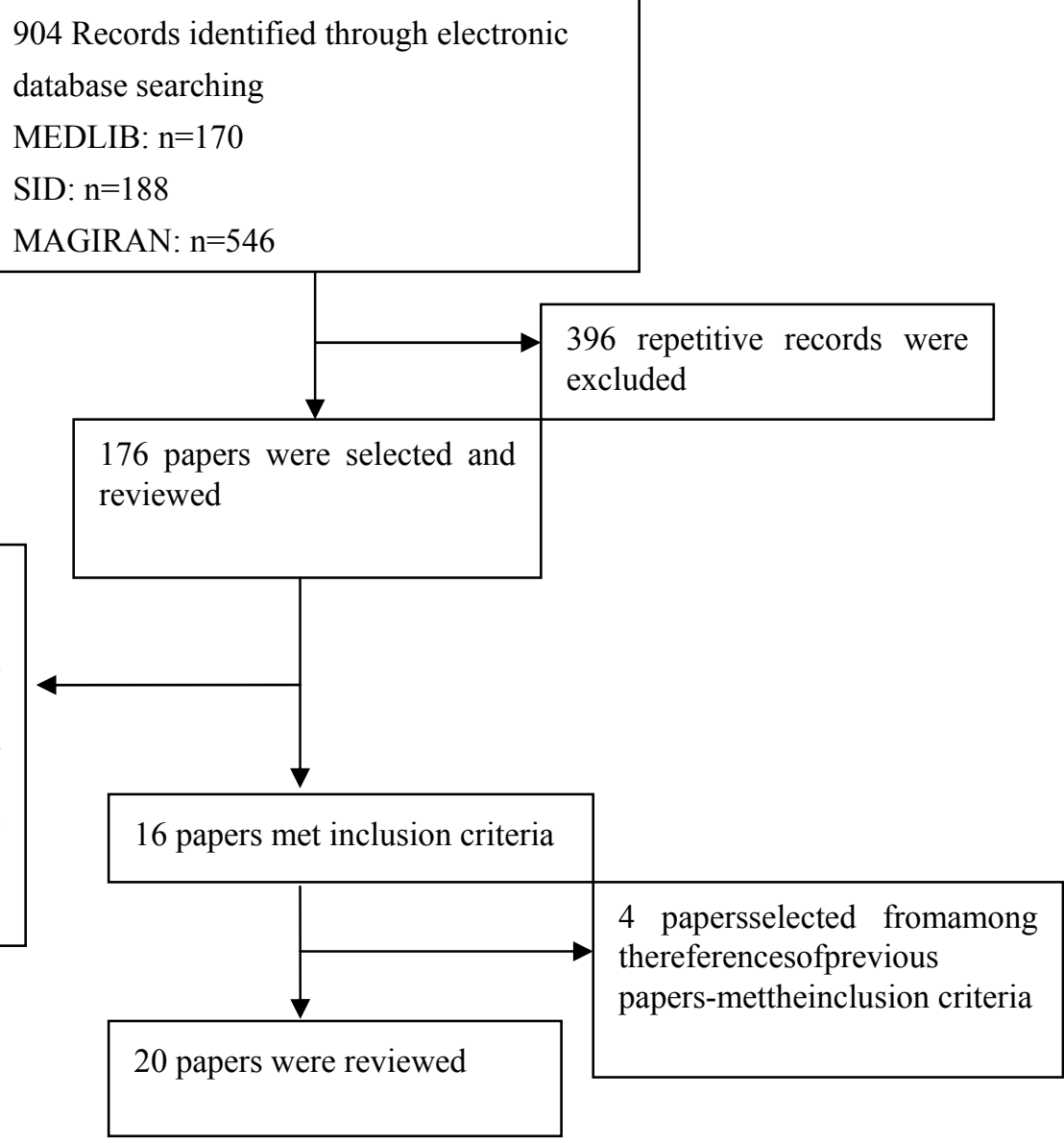

Flowchart 1. Stages of selecting and reviewing papers 


\section{Results}

All studies except for one case(Tabatabaei et al., 2010) showed that target intervention was effective in the promotion of physical activity. The most commonly used model in physical activity was the trans theoretical model (TTM) which was used in 9 studies. Other models and theories which were applied in the studies were the PENDER model (3 studies), the PRECEDE model (2studies), the theory of planned behavior (2 studies), the BANSEF model (2 studies), the self regulation theory (1 study), and the health belief model [HBM] (1 study). Regarding the type of the study, all studies were experimental, except for 8 quasi- experimental studies (Table 1). Of 20 trials, only 3 trials provided evidence of high quality. The sample size varied in different studies, ranging from 25 to 300 people. Five studies addressed maintenance of physical activity (performed in different periods of time) [Hazavehei et al,2009; Shakeri et al.,2012; Farmanbar et al, 2011;Peyman et al, 2012 \& Noroozi et al, 2011]. Approximately $65 \%$ of the studies explained the background and their reasons for selecting the model (Table 3). With regards to the educational methods, almost all studies used a combination of methods; $65 \%$ used lectures and 35\% used pamphlets. The peer education method and motivational interviewing were used in only one study (Solhi et al., 2012). As for the experiential methods, role playing was used in five and workshop in one study. The most important integrative method used in the studies was group discussion (14 studies). None of the studies measured the effectiveness of the educational method (Tables 1 and 2).

Table 1 . The results of the systematic review

\begin{tabular}{|c|c|c|c|c|c|c|c|c|}
\hline Author(s) & $\begin{array}{l}\text { The aim of the } \\
\text { study }\end{array}$ & Model/theory & $\begin{array}{l}\text { Target } \\
\text { group }\end{array}$ & $\begin{array}{l}\text { The typeof the } \\
\text { study* }\end{array}$ & $\begin{array}{l}\text { Duration of } \\
\text { intervention }\end{array}$ & $\begin{array}{l}\text { The method of } \\
\text { education }\end{array}$ & Results & Maintenance of behavior \\
\hline $\begin{array}{l}1 \text { Jalilian et al. } \\
\text { (2013) }\end{array}$ & $\begin{array}{l}\text { the effectiveness } \\
\text { of TTM-based } \\
\text { educational } \\
\text { intervention in } \\
\text { promotion of } \\
\text { regular physical } \\
\text { activity among } \\
\text { the staff }\end{array}$ & TTM & staff & $\begin{array}{l}\text { Quasi-Experime } \\
\text { ntal }\end{array}$ & 3 months & $\begin{array}{l}\text { Pamphlets, } \\
\text { booklets, CDs }\end{array}$ & $\begin{array}{l}\text { significant } \\
\text { progress during } \\
\text { the stages of } \\
\text { change; } \\
\text { significant } \\
\text { increase in TTM } \\
\text { constructs, and in } \\
\text { the level of } \\
\text { awareness; } \\
\text { counter } \\
\text { conditioning; } \\
\text { motivation } \\
\text { control; } \\
\text { self-libration and } \\
\text { helping } \\
\text { relationships }\end{array}$ & - \\
\hline $\begin{array}{l}2 \text { Farmanbar et } \\
\text { al. (2011) }\end{array}$ & $\begin{array}{l}\text { the impact of } \\
\text { intervention on } \\
\text { promotion and } \\
\text { maintenance of } \\
\text { athletic behavior } \\
\text { based on an } \\
\text { integration of } \\
\text { TTM and } \\
\text { self-determinatio } \\
\mathrm{n} \text { theory }\end{array}$ & $\begin{array}{l}\text { integration of } \\
\text { TTM and } \\
\text { self-determinatio } \\
\mathrm{n} \text { theory }\end{array}$ & $\begin{array}{l}\text { university } \\
\text { students }\end{array}$ & RCT & $\begin{array}{l}\text { before the } \\
\text { study, during } \\
\text { the study, and } \\
8 \text { months } \\
\text { afterthe study }\end{array}$ & $\begin{array}{l}\text { group } \\
\text { discussion, } \\
\text { public } \\
\text { meetings, } 4 \\
\text { educational } \\
\text { sessions } \\
\text { (45-60minuts), } \\
\text { CDs, booklets, } \\
\text { brochures, } \\
\text { SMS, reminder } \\
\text { cards }\end{array}$ & $\begin{array}{l}\text { changes in the } \\
\text { level of athletic } \\
\text { behavior and } \\
\text { post-intervention } \\
\text { stages of change }\end{array}$ & $\begin{array}{l}\text { significant increase in the } \\
\text { average athletic behavior in } \\
\text { the interventiongroup } 8 \\
\text { months after the intervention } \\
\text { versus during the study; } \\
\text { increase in the number of } \\
\text { people inthe preparation } \\
\text { stage, decrease in the number } \\
\text { of people in the stage of } \\
\text { action, increase in the } \\
\text { number of people in the stage } \\
\text { of maintenance; } \\
\text { decrease in the index } \\
\text { self-determination, } \\
\text { understanding of autonomy } \\
\text { and belonging }\end{array}$ \\
\hline $\begin{array}{l}3 \text { Moeini et al. } \\
\text { (2012) }\end{array}$ & $\begin{array}{l}\text { the impact of } 8 \\
\text { weeks of } \\
\text { educational } \\
\text { intervention on } \\
\text { promotion of } \\
\text { physical activity } \\
\text { in diabetic } \\
\text { patients }\end{array}$ & TTM & $\begin{array}{l}\text { diabetic } \\
\text { patients }\end{array}$ & $\begin{array}{l}\text { Quasi-Experime } \\
\text { ntal }\end{array}$ & $\begin{array}{l}\text { before the } \\
\text { intervention } \\
\text { and one month } \\
\text { after ( } 8 \text { weeks } \\
\text { of } \\
\text { intervention) }\end{array}$ & $\begin{array}{l}\text { lecture, } \\
\text { discussion, } \\
\text { hpamphlet, } \\
\text { booklet, CDs, } \\
\text { work out }\end{array}$ & $\begin{array}{l}\text { increase in the } \\
\text { stages of change } \\
\text { in exercising; } \\
\text { increase in the } \\
\text { average ofthe } \\
\text { constructs of } \\
\text { cognitive and } \\
\text { behavioral }\end{array}$ & \\
\hline
\end{tabular}




\begin{tabular}{|c|c|c|c|c|c|c|}
\hline & & & & & & $\begin{array}{l}\text { processes as well } \\
\text { as in } \\
\text { self-efficacy; } \\
\text { significant } \\
\text { difference in } \\
\text { applying the } \\
\text { levels of } \\
\text { processes of } \\
\text { cognitive and } \\
\text { behavioral } \\
\text { change }\end{array}$ \\
\hline $\begin{array}{l}4 \text { Solhi et al. } \\
\text { (2011) }\end{array}$ & $\begin{array}{l}\text { determination of TTM } \\
\text { the impact of } \\
\text { applying TTM on } \\
\text { physical activity }\end{array}$ & $\begin{array}{l}\text { pregnant } \\
\text { women }\end{array}$ & $\begin{array}{l}\text { Quasi-Experime } \\
\text { ntal }\end{array}$ & $\begin{array}{l}\text { before and } \\
\text { after the study }\end{array}$ & $\begin{array}{l}\text { lectures (5 } \\
\text { one-hour } \\
\text { sessions); } \\
\text { group } \\
\text { discussion; } \\
\text { showing } \\
\text { educational } \\
\text { films }\end{array}$ & $\begin{array}{l}\text { promotion in the } \\
\text { stages of change } \\
\text { (from } \\
\text { pre-contemplatio } \\
\mathrm{n} \text { to } \\
\text { contemplation } \\
\text { and to the } \\
\text { preparation } \\
\text { stage); increase in } \\
\text { the average of } \\
\text { perceived } \\
\text { benefits, } \\
\text { perceived } \\
\text { barriers, } \\
\text { perceived related } \\
\text { pleasure, and } \\
\text { perceived social } \\
\text { support; } \\
\text { increase in } \\
\text { physical activity }\end{array}$ \\
\hline $\begin{array}{l}5 \text { Hashemi et al. } \\
\text { (2013) }\end{array}$ & $\begin{array}{l}\text { determination of TTM } \\
\text { the impact of } \\
\text { education on the } \\
\text { level of physical } \\
\text { activity in } \\
\text { pregnant women }\end{array}$ & $\begin{array}{l}\text { pregnant } \\
\text { women }\end{array}$ & $\begin{array}{l}\text { controlled } \\
\text { interventional }\end{array}$ & 2 months & $\begin{array}{l}\text { discussing the } \\
\text { goals, booklet, } \\
\text { educational } \\
\text { cards, } \\
\text { educational } \\
\text { strategies to } \\
\text { draw attention, } \\
\text { motivational } \\
\text { interviews, } \\
\text { self-efficacy } \\
\text { promotion, } \\
\text { motivating } \\
\text { strategies, } \\
\text { consultation to } \\
\text { overcome } \\
\text { temptation } \\
\text { situations and } \\
\text { anxiety, } \\
\text { consultation on } \\
\text { the risk of } \\
\text { attention } \\
\text { deficit, } \\
\text { self-rewarding }\end{array}$ & $\begin{array}{l}\text { significant } \\
\text { increase in the } \\
\text { average of } \\
\text { awareness score, } \\
\text { attitude, and } \\
\text { model constructs } \\
\text { in the } \\
\text { intervention } \\
\text { group (perceived } \\
\text { benefits, } \\
\text { perceived } \\
\text { barriers, and } \\
\text {-self-efficacy) } \\
\end{array}$ \\
\hline $\begin{array}{l}6 \text { Moeini et al. } \\
(2010)\end{array}$ & $\begin{array}{l}\text { the impact of TTM } \\
\text { physical activity } \\
\text { educational } \\
\text { programs on the } \\
\text { promotion of } \\
\text { physical activity } \\
\text { and increasing } \\
\text { physical strength }\end{array}$ & staff & $\begin{array}{l}\text { Quasi-Experime } \\
\text { ntal }\end{array}$ & 12 weeks & $\begin{array}{l}\text { lecture, group } \\
\text { discussion, } \\
\text { workshop, } \\
\text { pamphlet, } \\
\text { booklet }\end{array}$ & $\begin{array}{l}\text { Significant } \\
\text { progress in the } \\
\text { stages of change; } \\
\text { increase in the } \\
\text { level of physical } \\
\text { strength, } \\
\text { self-efficacy, } \\
\text { balance, and sport } \\
\text { activities }\end{array}$ \\
\hline \multicolumn{2}{|c|}{$\begin{array}{l}7 \text { Ghahremani et application of TTM } \\
\text { al. (2008) TTM structures to }\end{array}$} & the elderl & experimental & 2 months & $\begin{array}{l}\text { individual } \\
\text { consulting } \\
\text { sessions; group }\end{array}$ & $\begin{array}{l}\text { Significant } \\
\text { difference in the } \\
\text { stages of }\end{array}$ \\
\hline
\end{tabular}




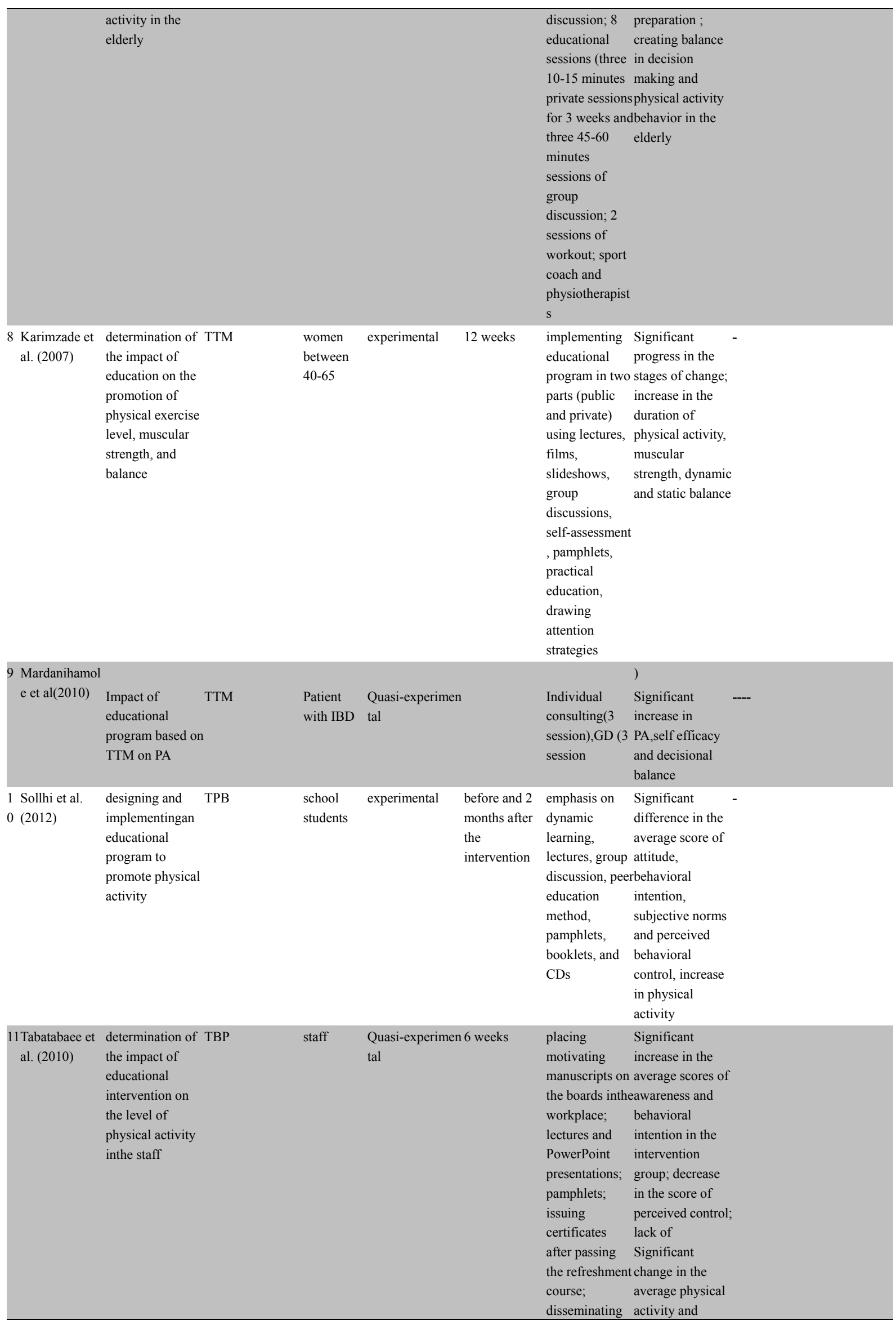




\begin{tabular}{|c|c|c|c|c|c|c|c|}
\hline & & & & & $\begin{array}{l}\text { photos and } \\
\text { messages } \\
\text { through Bulk } \\
\text { Messaging } \\
\text { systems every } 5 \\
\text { days; } \\
\text { disseminating } \\
\text { motivating } \\
\text { messages } \\
\text { weekly }\end{array}$ & $\begin{array}{l}\text { subjective norm } \\
\text { construct } \\
5\end{array}$ & \\
\hline $\begin{array}{l}1 \text { Estebsari et al. } \\
2 \text { (2010) }\end{array}$ & $\begin{array}{l}\text { determination of PRECEDE } \\
\text { the impact of } \\
\text { education on } \\
\text { physical activity } \\
\text { promotion on the } \\
\text { basis of } \\
\text { PRECEDE } \\
\text { Method }\end{array}$ & $\begin{array}{l}\text { junior high } \\
\text { school } \\
\text { students }\end{array}$ & $\begin{array}{l}\text { Quasi-experimen } \\
\text { tal }\end{array}$ & $\begin{array}{l}n \text { before and } 2 \\
\text { months after } \\
\text { the } \\
\text { intervention }\end{array}$ & $\begin{array}{l}\text { lectures, free } \\
\text { discussion, } \\
\text { pamphlets, } \\
\text { films, essay } \\
\text { writing and } \\
\text { newspaper } \\
\text { writing contestsi } \\
\end{array}$ & $\begin{array}{l}\text { increase in the } \\
\text { average score of } \\
\text { predisposing, } \\
\text { enabling, and } \\
\text { reinforcing } \\
\text { factors; } \\
\text { simproving } \\
\text { awareness and } \\
\text { attitude; } \\
\text { promotion in } \\
\text { physical activity }\end{array}$ & - \\
\hline $\begin{array}{l}1 \text { Saffari et al. } \\
3 \text { (2012) }\end{array}$ & $\begin{array}{l}\text { evaluation ofthe PRECEDE } \\
\text { impact of } \\
\text { educational } \\
\text { intervention } \\
\text { onthe life style } \\
\text { based on the } \\
\text { PRECEDE model }\end{array}$ & youth & $\begin{array}{l}\text { randomized } \\
\text { controlled trial }\end{array}$ & $\begin{array}{l}\text { before and } 2 \\
\text { months after } \\
\text { the } \\
\text { intervention }\end{array}$ & $\begin{array}{l}\text { educational } \\
\text { package, } 5 \\
\text { one-hour } \\
\text { sessions }\end{array}$ & $\begin{array}{l}\text { increase in the } \\
\text { average score of } \\
\text { standardized } \\
\text { physical activity } \\
\text { in boys rather } \\
\text { than girls }\end{array}$ & \\
\hline $\begin{array}{l}1 \text { Teimori et al. } \\
4 \text { (2007) }\end{array}$ & $\begin{array}{l}\text { determination of PENDER } \\
\text { the impact of } \\
\text { school } \\
\text { interventions on } \\
\text { physical activity } \\
\text { promotion }\end{array}$ & students & trial & 24 weeks & $\begin{array}{l}\text { education in } \\
\text { groups of } \\
5 / 7 / 12 \text { students } \\
\text { for } 30-45 \\
\text { minutes; short } \\
\text { lectures; } \\
\text { slideshows; } \\
\text { films; group } \\
\text { discussion; } \\
\text { question and } \\
\text { answer } \\
\text { meetings; } \\
\text { role-play; } \\
\text { individual } \\
\text { consultation; } \\
\text { reminder cards; } \\
\text { pamphlets }\end{array}$ & $\begin{array}{l}\text { increase in the } \\
\text { amount of time } \\
\text { devoted to daily } \\
\text { physical activity; } \\
\text { progress in the } \\
\text { stage of } \\
\text { preparation } \\
\text { caused by } \\
\text { intervention; } \\
\text { development in } \\
\text { perceived } \\
\text { self-efficacy and } \\
\text { perceived } \\
\text { behavior-related } \\
\text { pleasure; } \\
\text {; inter-personal } \\
\text { effects; having } \\
\text { plans for actions; } \\
\text { decrease in the } \\
\text { perceived barriers } \\
\text { and competitive } \\
\text { preferences }\end{array}$ & 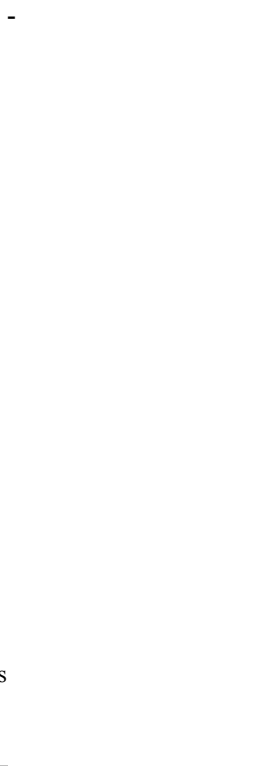 \\
\hline $\begin{array}{l}1 \text { Karimi et al. } \\
5 \text { (2011) }\end{array}$ & $\begin{array}{l}\text { determination of PRNDER } \\
\text { the impact of } \\
\text { education on the } \\
\text { promotion of } \\
\text { physical activity }\end{array}$ & $\begin{array}{l}\text { university } \\
\text { students }\end{array}$ & $\begin{array}{l}\text { before and after } \\
\text { random } \\
\text { controlled }\end{array}$ & two months & $\begin{array}{l}\text { six sessions } \\
\text { (lecture and } \\
\text { group } \\
\text { discussion); } \\
\text { targeting and } \\
\text { planning } \\
\text { strategies to } \\
\text { create } \\
\text { motivation }\end{array}$ & $\begin{array}{l}\text { Significant } \\
\text { difference in the } \\
\text { average scores of } \\
\text { variables inthe } \\
\text { Health Promotion } \\
\text { Model (perceived } \\
\text { benefits and } \\
\text { barriers, } \\
\text { self-efficacy, } \\
\text { inter-personal } \\
\text { effective factors); } \\
\text { better } \\
\text { performance at } \\
\text { the end of the } \\
\text { program }\end{array}$ & \\
\hline 1 Noroozi et al. & studying the & diabetic & Quasi-experimen & $n$ at the & group & change in the & increase in the number of \\
\hline
\end{tabular}




\begin{tabular}{|c|c|c|c|c|c|c|c|c|}
\hline $6(2011)$ & $\begin{array}{l}\text { impact of } \\
\text { education on } \\
\text { physical activity }\end{array}$ & & women & tal & $\begin{array}{l}\text { beginning of } \\
\text { the study, } 3 \\
\text { months and } 6 \\
\text { months after } \\
\text { the study }\end{array}$ & $\begin{array}{l}\text { education (one } \\
\text { session); } \\
\text { private } \\
\text { consultation } \\
\text { usingthe 5A } \\
\text { method (3 } \\
\text { sessions) }\end{array}$ & $\begin{array}{l}\text { level of physical } \\
\text { activity; } \\
\text { difference in the } \\
\text { levels of activity } \\
\text { betweencases }\end{array}$ & $\begin{array}{l}\text { individuals in the action and } \\
\text { maintenance stages as well as } \\
\text { decrease in the level of } \\
\text { physical activity in the } 6^{\text {th }} \\
\text { month (in comparisonwith } \\
\text { the } 3^{\text {rd }} \text { month) }\end{array}$ \\
\hline $\begin{array}{l}1 \text { Hazave'ei et a } \\
7(2009)_{]}\end{array}$ & $\begin{array}{l}\text { the impact of } \\
\text { PE(2) on regular } \\
\text { physical activity } \\
\text { based on the } \\
\text { BASNEFmodel }\end{array}$ & BASNEF & $\begin{array}{l}\text { female } \\
\text { university } \\
\text { students }\end{array}$ & & $\begin{array}{l}\text { before, and } 2 \\
\text { and } 4 \text { months } \\
\text { after }\end{array}$ & $\begin{array}{l}8 \text { educational } \\
\text { sessions ( } 30 \\
\text { minutes) } \\
\text { lecture, film, } \\
\text { question and } \\
\text { answer, } \\
\text { discussion, } \\
\text { pamphlets, } \\
\text { CDs, answering } \\
\text { the students' } \\
\text { questions via } \\
\text { telephone }\end{array}$ & $\begin{array}{l}\text { better } \\
\text { performance } \\
\text { ofthe intervention } \\
\text { group in physical } \\
\text { activity } 2 \text { and } 4 \\
\text { months after the } \\
\text { interventions; } \\
\text { significant } \\
\text { gchange inthe } \\
\text { average scores of } \\
\text { BASNEF } \\
\text { constructs } \\
\text { (enabling factor, } \\
\text { subjective norms, } \\
\text { attitude toward } \\
\text { regular physical } \\
\text { activity, attitude } \\
\text { toward the } \\
\text { outcomes of } \\
\text { regular physical } \\
\text { activity) }\end{array}$ & $\begin{array}{l}\text { decrease in the score of } \\
\text { awareness, attitude toward } \\
\text { loutcomes, enabling factors, } \\
\text { and intention in first and } \\
\text { second follow-up than the } \\
\text { immediate stage after } \\
\text { intervention; } \\
\text { decrease in the score of } \\
\text { attitude in the first follow-up } \\
\text { and increase in the second } \\
\text { follow-up; } \\
\text { increase in determined } \\
\text { decision to do physical } \\
\text { exercise in the first and } \\
\text { second follow-up than the } \\
\text { immediate stage after the } \\
\text { intervention }\end{array}$ \\
\hline $\begin{array}{l}1 \text { Shakeri et al. } \\
8 \text { (2012) }\end{array}$ & $\begin{array}{l}\text { determination of } \\
\text { the impact of } \\
\text { educational } \\
\text { intervention on } \\
\text { the level of } \\
\text { physical activity } \\
\text { in pregnant } \\
\text { women based on } \\
\text { the BASNEF } \\
\text { Model }\end{array}$ & & $\begin{array}{l}\text { pregnant } \\
\text { women }\end{array}$ & quasi-empirical & $\begin{array}{l}\text { before, and } \\
\text { immediately, } \\
\text { and } 6 \text { weeks } \\
\text { after the } \\
\text { intervention }\end{array}$ & $\begin{array}{l}\text { CDs, } \\
\text { pamphlets, } \\
\text { booklets, } \\
\text { lectures, group } \\
\text { discussion. } \\
\text { films, question } \\
\text { and answer } \\
\text { sessions, work } \\
\text { out in groups in } \\
\text { the presence of } \\
\text { an expert }\end{array}$ & $\begin{array}{l}\text { difference in the } \\
\text { scores of attitude, } \\
\text { awareness, } \\
\text { enabling factors, } \\
\text { and subjective } \\
\text { norms; promotion } \\
\text { of physical } \\
\text { activity in the } \\
\text { group }\end{array}$ & $\begin{array}{l}\text { increase in the score of } \\
\text { knowledge,attitude,subjectiv } \\
\text { e norms, and enabling factors } \\
\text { in the intervention group }\end{array}$ \\
\hline $\begin{array}{l}1 \text { Peyman et al. } \\
9 \text { (2012) }\end{array}$ & $\begin{array}{l}\text { determination of } \\
\text { the impact of } \\
\text { education on } \\
\text { self-regulation } \\
\text { strategies }\end{array}$ & self-regulation & $\begin{array}{l}\text { diabetic } \\
\text { women }\end{array}$ & $\begin{array}{l}\text { randomized } \\
\text { controlled } \\
\text { clinical trial }\end{array}$ & $\begin{array}{l}\text { before, after } \\
\text { and } 10 \text { weeks } \\
\text { after the } \\
\text { intervention }\end{array}$ & $\begin{array}{l}7 \text { one-hour } \\
\text { sessions (4 } \\
\text { theoretical } \\
\text { sessions and } 3 \\
\text { sessions of } \\
\text { workout), } \\
\text { group } \\
\text { discussion, } \\
\text { brain storming, } \\
\text { lectures, } \\
\text { posters, } \\
\text { pamphlets, fact } \\
\text { sheets, DVD }\end{array}$ & $\begin{array}{l}\text { Significant } \\
\text { difference in } \\
\text { targeting, } \\
\text { planning, } \\
\text { awareness and the } \\
\text { level of physical } \\
\text { activity; } \\
\text { significant } \\
\text { decrease in the } \\
\text { level of blood } \\
\text { sugar and body } \\
\text { mass index }\end{array}$ & $\begin{array}{l}\text { decrease in the scores of } \\
\text { targeting, planning, and } \\
\text { awareness in follow-up } \\
\text { stages than the stage after } \\
\text { eintervention; } \\
\text { decrease in the level of } \\
\text { physical activity in the } \\
\text { follow-up stage }\end{array}$ \\
\hline $\begin{array}{l}2 \text { Abedi et al. } \\
0(2011)\end{array}$ & $\begin{array}{l}\text { determination of } \\
\text { the impact of } \\
\text { Health Belief } \\
\text { Model on the } \\
\text { cardiovascular } \\
\text { risk factors }\end{array}$ & $\begin{array}{l}\text { Health Belief } \\
\text { Model }\end{array}$ & \multicolumn{2}{|c|}{$\begin{array}{l}\text { menopausa clinical trial } \\
1 \text { women }\end{array}$} & $\begin{array}{l}\text { before and } 6 \\
\text { months after } \\
\text { the } \\
\text { intervention }\end{array}$ & $\begin{array}{l}\text { One } \\
\text { face-to-face } \\
\text { educational } \\
\text { session; one } \\
\text { session at the } \\
\text { end of the third } \\
\text { month; three } \\
\text { one-hour } \\
\text { sessions using } \\
\text { aid kits in the } \\
\text { first month and } \\
\text { at the end of } \\
\text { every week, } \\
\text { pamphlet, }\end{array}$ & $\begin{array}{l}\text { increase in } \\
\text { physical activity } \\
\text { ( } 272 \text { minutes a } \\
\text { week); increase in } \\
\text { knowledge, } \\
\text { perceived } \\
\text { severity, and } \\
\text { perceived } \\
\text { susceptibility }\end{array}$ & - \\
\hline
\end{tabular}


Table 2. Dirubtion of Educational Methods in Physical activity Theory Based interventions in Iran

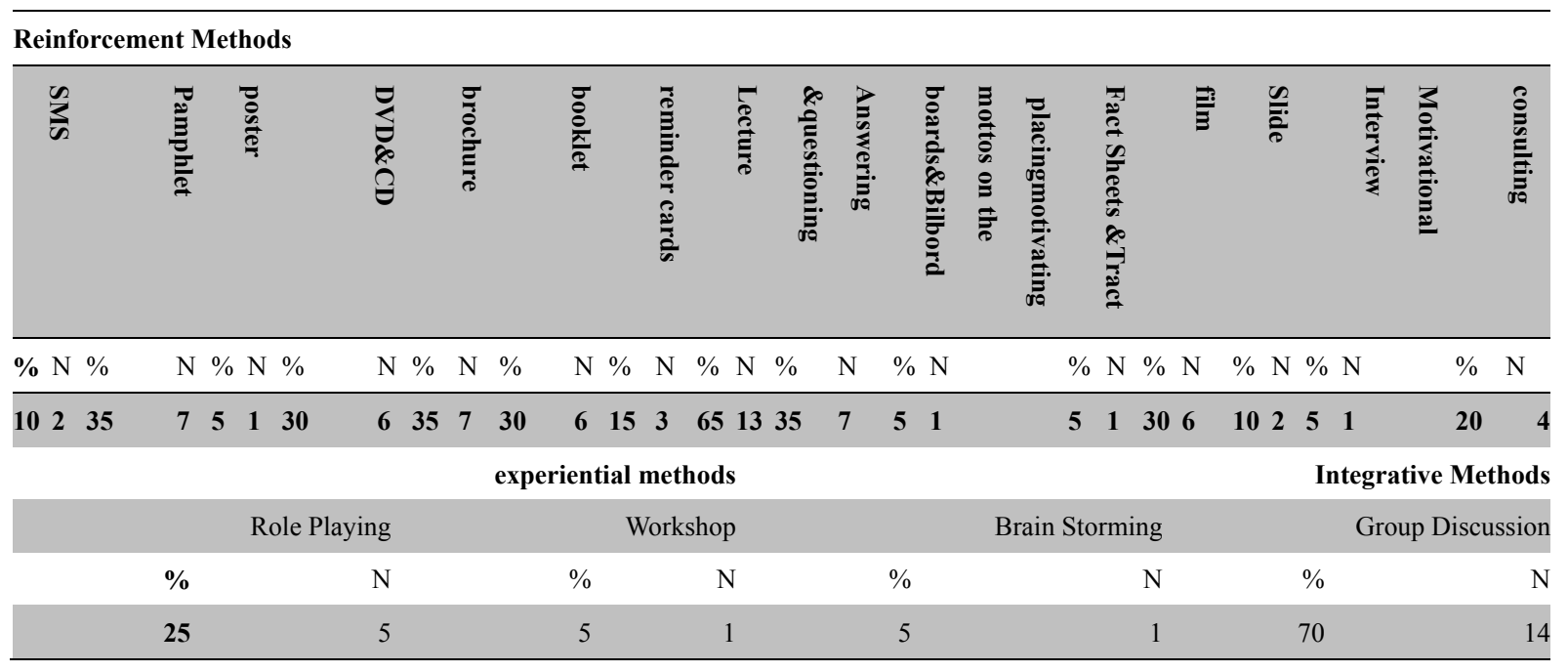

Table 3. Methodological quality of the included studies

\begin{tabular}{|c|c|c|c|c|c|c|c|c|c|}
\hline $\begin{array}{l}\overrightarrow{0} \\
\overrightarrow{0} \\
\overrightarrow{9} \\
\overrightarrow{0} \\
\overrightarrow{0} \\
0\end{array}$ & 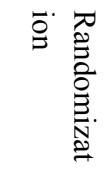 & $\underset{\infty}{\stackrel{\varpi}{E}}$ & 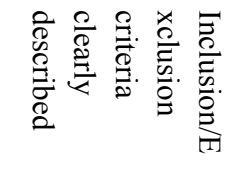 & 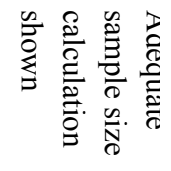 & 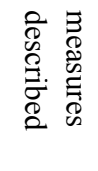 & 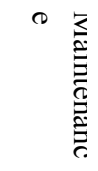 & 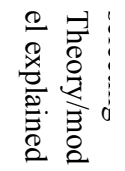 & 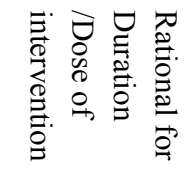 & 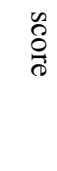 \\
\hline Karimi et al. (2012) & 1 & 0 & 1 & 0 & 1 & 0 & 1 & 0 & $4 / 8$ \\
\hline Tabatabaei et al. (2010) & 1 & 1 & 0 & 0 & 1 & 0 & 1 & 0 & $4 / 8$ \\
\hline Abedi et al. (2011) & 1 & 0 & 1 & 0 & 1 & 0 & NA & 0 & $3 / 8$ \\
\hline Hazaveei et al. (2009) & 1 & 0 & 1 & 0 & 1 & 1 & 0 & 0 & $4 / 8$ \\
\hline Jalilian et al. (2012) & 1 & 0 & 0 & 0 & 1 & 0 & 1 & 0 & $3 / 8$ \\
\hline Moeini et al. (2010) & 1 & 0 & 1 & 0 & 1 & 0 & 1 & 0 & $4 / 8$ \\
\hline Hashemi et al. (2013) & 1 & 0 & 1 & 1 & $\mathrm{NA}^{2}$ & 0 & 1 & 0 & $4 / 8$ \\
\hline Solhi et al. (2011) & 1 & 0 & 1 & 0 & NA & 0 & 1 & 0 & $3 / 8$ \\
\hline Shakeri et al. (2012) & 1 & 0 & 1 & 1 & 1 & 1 & 0 & 0 & $5 / 8$ \\
\hline Timori et al. (2007) & 1 & 0 & 1 & 0 & 1 & 0 & 1 & 1 & $5 / 8$ \\
\hline Peyman et al. (2012) & 1 & 0 & 1 & 0 & 1 & 1 & 1 & 0 & $5 / 8$ \\
\hline Saffari et al. (2012b) & 1 & 0 & 1 & 1 & 1 & 0 & 0 & 1 & $5 / 8$ \\
\hline Solhi et al. (2012) & 1 & 0 & 1 & 1 & 1 & 0 & 1 & 1 & $6 / 8$ \\
\hline Estebsari et al. (2010) & 1 & 0 & 0 & 1 & 1 & 0 & 0 & 0 & $3 / 8$ \\
\hline Noroozi et al. (2011) & 1 & 0 & 1 & 0 & 1 & 1 & 1 & 1 & $6 / 8$ \\
\hline Farmanbar et al. (2001) & 1 & 0 & 1 & 0 & 1 & 1 & 1 & 1 & $6 / 8$ \\
\hline Moeini et al. (2011) & 1 & 0 & 1 & 0 & 1 & 0 & 1 & 1 & $5 / 8$ \\
\hline $\begin{array}{l}\text { Mardanihamole et al. } \\
\text { (2010) }\end{array}$ & 1 & 0 & 1 & 0 & 1 & 0 & 1 & 1 & $5 / 8$ \\
\hline $\begin{array}{l}\text { Karimzadehshirazi et al. } \\
\text { (2007) }\end{array}$ & 1 & 0 & 1 & 0 & 1 & 0 & 1 & 1 & $5 / 8$ \\
\hline $\begin{array}{l}\text { Ghahremani et al. } \\
(2008)\end{array}$ & 1 & 0 & 1 & 0 & 1 & 0 & 0 & 1 & $4 / 8$ \\
\hline
\end{tabular}




\section{Discussion}

The present review investigated the theory based intervention in PA in Iran and the effect of these interventions.

\subsection{Main Results}

Approximately all the studies conducted in Iran focused on the individual or intrapersonal level, and individuals were the primary target audience of the health education materials.

All studies except for one case stated that target intervention was effective in the promotion of physical activity.

The studies were heterogeneous and had different sample sizes (ranging from 25-300). All the studies relied on self-reporting. The interventions differed in target populations, duration of intervention, and settings. Of 20 trials, only 3 provided evidence of high quality.

Almost all studies used a combination of methods. PA maintenance was not addressed in $75 \%$ of the studies.

\subsection{Summary of the Lessons Learned From This Review}

Most of the studies that conducted in Iran had methodological weaknesses.

In $30-40 \%$ of the studies, the reasons for choosing the theories/models were not specified.

The social and ecological models were not addressed, Although social marketing and social-cognitive theory are applicable models/theories in physical activity, we could not find any records that were designed and implemented based on these models/theories in Iran.

\subsection{Theoretical Basis for Intervention}

Of nine studies based on TTM, all reported positive results in the treatment group. When compared to the control group, the treatment group had a significant progress during the stages of change and TTM constructs (Table 1).

Of two studies based on TPB, Tabatabaee et al. (2010) reported that TPB did not lead to an increase in physical activity. Azjen and Fishbein (2004) showed that the predictability of TPB differed from behavior to behavior and from population to population.

In Iran, only three studies had the inclusion criteria of PENDER.all of these studies had some positive results.

In studies performed by Saffari et al. (2012b); Estebsari et al. (2010); Pyman et al. (2012) and Abedi et al. (2011), the theory/model was partially implemented.

Only two studies contained BASNEF inclusion criteria. They did not deal with the application of BASNEF model in physical activity studies,but the maintenance of physical activity was addressed in studies by Hazavehei et al. (2009), 4 months after the interventions and Shakeri et al(2012), 6 weeks after the intervention.

\subsection{Overall Completeness and Applicability of Evidence}

Of twenty trials, 7 were conducted in the school/university and 3 in the workplace. the others were conducted in clinical settings .Most studies included promotion of PA as a main objective. All of them provided multiple sessions. One trial focused on elderly people. Almost all studies used a combination of methods.

Methods are the means or ways that we use to deliver the material to our clients. In a classification, educational methods are divided into three categories: 1) reinforcement methods 2) integrative methods and 3) experiential methods (Saffari et al, 2012a). Most educators agree that reinforcement methods such as lectures are necessary (Saffari et al., 2012a; Tyler et al., 2009), but they believe that they should be limited in number and well delivered. It is important to give the learners the opportunities to apply and reflect on lecture material during course time.Our findings showed that the most important educational methods that were used in the studies were the reinforcement method ( $65 \%$ used lectures). Lectures are efficient ways of delivering information. but the weaknesses of lecture should be considered.

Traditionally, small groups consist of 8-12 participants. Small groups can take on a variety of different tasks, including problem solving, role play, discussion, brainstorming, debate, workshops, and presentations. In our study, the most widely used integrative educational method was group discussion.

The main advantages of small group learning are that it encourages active learning and develops communication and teamwork skills.

The peer education method and motivational interviewing were used in only one study.

\subsection{Limitations and Quality of the Evidence}

Of 20 trials, only 3 provided evidence of high quality (Table 3 ). 
All the studies reviewed here relied on self-reporting (except for Moeini et al, 2010). The reliability of self-reporting is questionable .Because of social desirability and other types of information bias, self report is not the most reliable indicator of behavior (Lopez, Tolley, Grimes, Chen, \& Stockton, 2013).

Choosing a theory should start with a "thorough assessment of the situation: the units of analysis or change, the topic, and the type of behavior to be addressed" (WHO, 2012). We found that, some studies specifically stated their reasons for selecting the theory/model, while, many studies did not provide sufficient information about the assessment of the situation.

Sample size calculation was poorly reported. Only one trial provided blinding of participants (Tabatabaei et al., 2010). The flow of participants was reported in none of the studies .Randomization details were frequently unclear.

Because of the variation in the duration of intervention(ranging from immediately to 24 week) the studies that conducted in Iran does not provide enough evidence on the optimal duration of most effective intervention for promoting physical activity. This is consistent with a systematic review performed by Chen and Wilkosz (2014).

Effectiveness may be limited when the theory/model is partially implemented (Lopez et al., 2013). Peyman et al. (2012), used only two components of the self-regulation theory (SRT), e.g. setting goals and perusing goals. Other components of SRT were not addressed in their study.As Saffari et al. (2012b) mentioned, some stages of PRECEDE (such as genetic diagnosis) could be ignored. Estebsari et al. (2010), evaluated the stages of educational diagnosis (predisposing, enabling, reinforcing).

Constructs such as awareness, perceived susceptibility, perceived severity, perceive benefits, and perceived barriers were evaluated in a study by Abedi et al. (2011). A recent addition to the HBM is the concept of self-efficacy, which was added to the model in 1980. Bendura reported that self-efficacy was one of the most important structures in such behaviors as physical activity (Moeini et al., 2010; Jallilian et al., 2013). In the study by Abedi et al. (2011), self-efficacy was not evaluated.

\subsubsection{TTM}

Our Findings show that TTM is frequently used in physical activity studies in Iran. In spite of its popularity, TTM has its own limitations. First, the reliability of self-reporting is questionable. All the studies reviewed here relied on self-reporting. Only Moeini et al. (2010) used Ergo line bicycle to evaluate the physical strength in the sample population. Second, the TTM lacks predictability. It has not been addressed in the studies published in Iran. Some scholars, however, consider this model as a descriptive, not a predictive one (Sharma \& Romas, 2008).

Our systematic review revealed that several questionnaires were used to measure the constructs of the TTM.For example, Jalilian et al (2013) used 5 questionnaires. Being economical is considered as one of the characteristics of a good theory or model and the TTM is not an economical model (Saffari et al., 2012a). Another limitation of the TTM is that people can easily pass stages or return to the previous stages. No study in Iran ever dealt with the issue of returning to previous stages.

\subsubsection{TPB}

One of the limitations of TPB is that it assumes that perceived behavioral control can predict actual behavior control. It is confirmed by the decrease in perceived behavior control observed in the study performed by Tabatabaei et al (2010). Measurement of intention requires measurement of its predictors which in the context of TPB is most commonly inferred from questionnaire responses and measuring behavior using self-reporting is another limitation of TPB. Self-reporting has been used as a measure in TPB-based studies in Iran. Ajzen and Fishbein (2004) reported that "such behaviors as physical activity were time-consuming and expensive to study" (Saffari et al., 2012a).

\subsubsection{PENDER}

One of the main disadvantages of this model is that it contains too many constructs, and is not economical. For example, Teimori et al (2007) used 7 questionnaires. It does not seem economical or easy to control. It is also quite time-consuming (Saffari et al, 2012a).

\subsubsection{Other Models}

Implementing PRECEDE needs significant financial sources. According to Saffari et al (2012b), it is usually impossible to evaluate outcomes in this model.

Since HBM focuses on a limited number of factors and ignores cultural, social, and economical factors and the 
previous experiences of people, it essentially lacks predictability (Saffari et al., 2012a).

One of the main challenges in health education and promotion is the maintenance of the behavior which was considered in only 5 studies in different periods of time without any explanation on the reason.

\section{Conclusion}

This review can be used to design and implement theory/model based interventions in physical activity, but the methodological weaknesses among the studies (e.g lack of sample size adequacy, variation in the duration of intervention, lack of rationale for selecting models/theories, etc ...) should be considered. Limitations and weaknesses listed above could affect the validity and applicability of the results of these studies.

Considering the findings of the study, the authors suggest that:

Maintenance in PA and integrating models in the field of physical activity should be addressed;

Future researches should include long term follow ups, longer intervention periods, and larger sample sizes to evaluate the effectiveness of theory -based interventions in PA.

Health promotion programs are more effective when planners consider multiple levels of influence on health problem .Lack of addressing interpersonal and community levels in Iranian trials is important and should be included in future research. Moreover, epidemiology methodology consultation is necessary.

The reliability and validity of assessment tools in Iranian studies must be one of the important priorities. Some other effective social and ecological models in the field of physical activity are social marketing and social-cognitive theory which were not performed in Iran. It is suggested that future studies include these models.

\section{Acknowledgments}

The authors wish to acknowledge the grammatical revision of the manuscript in English facilitated by the Consultation Unit, Office of Publications and Scientometrics, Tehran University of Medical Sciences.

\section{Conflict of Interest Statement}

The authors declare that they have no conflict of interest.

\section{References}

Abbaszadeh, A., Borhani, F., \& Asadi, N. (2011). Effects of health belief model-based video training about risk factors on knowledge and attitude of myocardial infarction patients after discharge. J Res Med Sci, 16(2), 195-199.

Abedi ,P., Lee, MHSLHS., Kandiah, M. K., Yassin, Z., Shojaeezade, D., \& Hosseini, M. (2011). Lifestyle Change Using the Health Belief Model to Improve Cardiovascular Risk Factors among Postmenopausal Women. Health System Research, 7(1), 127-37.

Ajzen, I., \& Fishbein, M. (2004). Questions raised by a reasoned action approach: comment on Ogden (2003). Health Psychol, 23(4), 431-434. http://dx. doi.org/ 10.1037/0278-6133.23.4.431

Ar-Yuwat, S., Clark, M. J., Hunter, A., \& James, K. S. (2013). Determinants of physical activity in primary school students using the health belief model. $J$ Multidiscip Healthc, 6, 119-126. http://dx.doi.org/10.2147/JMDH.S40876

Bandura, A. (2004). Health promotion by social cognitive means. Health Educ Behav, 31(2), 143-164. http://dx.doi.org/10.1177/1090198104263660

Brooke, H. L., Corder, K., Griffin, S. J., \& van Sluijs, E. M. (2014). Physical activity maintenance in the transition to adolescence: a longitudinal study of the roles of sport and lifestyle activities in British youth. PLoS One, 9(2), e89028. http://dx. doi.org/ 10.1371/journal.pone.0089028

Brooks, R. J., Higgins, G. Y., \& Webster, A. C. (2010). Systematic review of randomized controlled trial quality in pediatric kidney transplantation. Pediatr Nephrol, 25(12), 2383-2392. http://dx.doi.org/10.1007/s00467-010-1595-x

Chen, J. L., \& Wilkosz, M. E. (2014). Efficacy of technology-based interventions for obesity prevention in adolescents: a systematic review. Adolesc Health Med Ther, 5, 159-170. http://dx.doi.org/10.2147/AHMT.S39969

Estebsari, F., Shojaeezade, D., Mostafaei, D., \& Farahbakhsh, M. (2010). Planning and Evaluation of an Educational Program Based on PRECEDE Model to Improve Physical Activity in Female Students. The 
Journal of Faculty of Nursing \& Midwifery, 16(1), 48-54.

Esteghamati, A., Khalilzadeh, O., Rashidi, A., Kamgar, M., Meysamie, A., \& Abbasi, M. (2011). Physical activity in Iran: results of the third national surveillance of risk factors of non-communicable diseases (SuRFNCD-2007). J Phys Act Health, 8(1), 27-35.

Farmanbar, R. A., Niknami, Sh., \& Heydarnia, A. R. (2011). REffect of an Integrated Trans theoretical Model and Self-Determination Theory on the Promotion and Maintenance of Exercise Behavior. Journal of Guilan University of Medical Sciences, 21(82), 46-56.

Geller, K. S., Nigg, C. R., Motl, R. W., Horwath, C., \& Dishman, R. K. (2012). Transtheoretical Model Constructs for Physical Activity Behavior are Invariant across Time among Ethnically Diverse Adults in Hawaii. Psychol Sport Exerc, 13(5), 606-613. http://dx. doi.org/ 10.1016/j.psychsport.2012.02.006

Ghahremani, L., Niknami, Sh., Mosavi, M. T., Heidarnia, A. R., Karimzadeh Shirazi, K., \& Babaei, Gh. (2008). Trans theoretical Model-based (TTM) Interventions to Improve Physical Activities in Elderly Men. Armaghane-danesh, 13(1), 76-88.

Glanz, K., \& Bishop, D. B. (2010). The role of behavioral science theory in development and implementation of public health interventions. Annu Rev Public Health, 31, 399-418. http://dx.doi.org/10.1146/annurev.publhealth.012809.103604

Glanz, K., Lewis, F. M., \& Rimer, B. K. (2002). Health Behaviour and Health Education: Theory, Research and Practice. San Francisco, CA: Jossey-Bass.

Haakstad, L. A., Voldner, N., \& Bo, K. (2013). Stages of change model for participation in physical activity during pregnancy. J Pregnancy, 2013, 193170. http://dx.doi.org/10.1155/2013/193170

Hashemi, S. Z., Rakhshani, F., Navidian, A., \& Mosavi, S. R. (2013). Effectiveness of Educational Program based on Trans-Theoretical Model on Rate of Physical Activity among Household Women in Zahedan, Iran. J. Health System Research, 9(2), 144-152.

Hazavehei, S. M., Khani Jeihooni, A., Hasanzadeh, A., \& Amini, S. (2010). The Effect of Educational Program Based on BASNEF Model for Eye Care in Non-insulin Dependent Diabetic Patients. J Res Health Sci, 10(2), 81-90.

Hazavehei, S. M., Asadi, Z., Hassanzadeh, A., \& Shakarchizadeh, P. (2009). A Study on the Effect of Physical Education (2) Curriculum Based on BASNEF Model on Female Students' Regular Physical Activity in Isfahan University of Medical Sciences. Journal of Zanjan University Medical Science., 17(69), 70-83.

Jalilian, M., Darabi, M., Sharifirad, Gh., \& Kakaei, H. (2013). Interventional Program based on Trans-Theoretical Model to Promote Regular Physical Activity in Office Workers. J Health Syst Res, 9(2), 188-19.

Karimzadeh Shirazi, K., Niknami, Sh., Heydarnia, A., Wallace, L. M., Torkaman, G., \& Faghihzadeh, S. (2007). Effects of aTTM-based osteoporosis preventive physical activity education, on increasing muscle strength and balance in women aged 40-65. Hakim Res J, 10(2), 34-42.

karimi, M., \& Eshrati, B. (2012). The effect of health promotion model-based training on promoting students' physical activity. Journal of Kermanshah Medical University, 16(3), 192-200.

Koohpayehzadeh, J., Etemad, K., Abbasi, M., Meysamie, A., Sheikhbahaei, S., Asgari, F., . . Esteghamati, A. (2014). Gender-specific changes in physical activity pattern in Iran: national surveillance of risk factors of non-communicable diseases (2007-2011). Int J Public Health, 59(2), 231-241. http://dx.doi.org/ 10.1007/s00038-013-0529-3

Lee, P. H., Macfarlane, D. J., Lam, T. H., \& Stewart, S. M. (2011). Validity of the International Physical Activity Questionnaire Short Form (IPAQ-SF): a systematic review. Int $J$ Behav Nutr Phys Act, 8, 115. http://dx.doi.org/10.1186/1479-5868-8-115

Lopez, L. M., Tolley, E. E., Grimes, D. A., Chen, M., \& Stockton, L. L. (2013). Theory-based interventions for contraception. Cochrane Database Syst Rev, 8, CD007249. http://dx.doi.org/ 10.1002/14651858.CD007249.pub4

Lusk, S. L., Ronis, D. L., \& Hogan, M. M. (1997). Test of the health promotion model as a causal model of construction workers' use of hearing protection. Res Nurs Health, 20(3), 183-194.

Mardanihamole, M., Shahrakivahed, A., \& Moshtageshg, Z. (2010). Assessment the effect of educational 
program based on TTM on physical activity of patient with Inflammatory Bowel Diseases. Journal of Hamadan university of medical science, 17(1), 39-45.

Moeini, B., Hazavehei, S. M., Jalilian, M., Moghimbeigi, A., \& Seresht, T. (2011). Factors Affecting Physical Activity andMetabolic Control in Type 2 Diabetic Women Referred to the Diabetes Research Center of Hamadan: ApplyingTrans-Theoretical Model. Sci J Hamadan Univ Med Sci, 18(2), 31-37.

Moeini, B., Rahimi, M., Hazaveie, SM., Allahverdipoor, H., Moghimbeygi, A., \& Mohammadfam, I. (2010). Effect of educationbased on trans-theoretical model on promoting physical activity and increasing physical work capacity. J Mil Med, 12(3), 123-30.

Mohamaei, F., Nouri Tajer, M., Noohi, F., \& Maleki, M. (2004). Application of BASNEF Health Belief Model in Preventing the Occurrence of Risk Factors Contributing to Myocardial Infarction in Patients with Coronary Artery Disease. Iranian Heart Journal, 5(1,2), 29-32.

Nigg, C. R., Geller, K. S., Motl, R. W., Horwath, C. C., Wertin, K. K., \& Dishman, R. K. (2011). A Research Agenda to Examine the Efficacy and Relevance of the Transtheoretical Model for Physical Activity Behavior. Psychol Sport Exerc, 12(1), 7-12. http://dx. doi.org/10.1016/j.psychsport.2010.04.004

Noroozi, A., Tahmasebi, R., Ghofranipour, F., \& Hydarnia, A. (2011). Effect of Health Promotion Model (HPM) Based Education onPhysical Activity in Diabetic Women. Iranian Journal of Endocrinology and Metabolism, 13(4), 361-367.

Oluka, O. C., Nie, S., \& Sun, Y. (2014). Quality assessment of TPB-based questionnaires: a systematic review. PLoS One, 9(4), e94419. http://dx. doi.org/10.1371/journal.pone.0094419

Oyeyemi, A. L., Oyeyemi, A. Y., Adegoke, B. O., Oyetoke, F. O., Aliyu, H. N., Aliyu, S. U., \& Rufai, A. A. (2011). The Short International Physical Activity Questionnaire: cross-cultural adaptation, validation and reliability of the Hausa language version in Nigeria. BMC Med Res Methodol, 11, 156 http://dx.doi.org/10.1186/1471-2288-11-156

Pender, N. (2011). The Health Promotion Model Manual. Retrieved from http://nursing.umich.edu/faculty-staff/nola-j-pender.

Peyman, N., Taghipour, A., Mahdizadeh, M., \& Esmaeely, H. (2012). The Effect of Educational Intervention Based on Self-Regulation Strategies on Physical Activity in Women with Type 2 Diabetes. Journal of Evidence-based Care, 2(4), 7-16.

Pirasteh, A. J., Zafarghandi, Z., \& Kholdi, N. (2012). Enviromental Factors Affecting Physical Activity and Health promotion Of Students based on Social Cognitive Theory. Alborz University Medical Journal, 1(3), 159-165.

Raheem, J., \& Paxton et al. (2008). Are Constructs of the Transtheoretical Model for Physical Activity Measured Equivalently Between Sexes, Age Groups, and Ethnicities? Ann Behav Med, 35(3), 308-318.

Saffari, M., Shojaeezade, D., Ghofrani Pour, F., Heydarnia, A., \& Pakporhajiagha, A. (2012a). Theories, models and methods of health education and health promotion (2nd ed). Tehran, Iran: AsareSobhan Publication.

Saffari, M., Amini, N., Ardebili, H. E., Mahmoudi, M., \&Sanaeinasab, H. (2012b). Evaluation of an educational intervention based on PRECEDE PROCEED model toward lifestyle improvement among adolescents. Daneshvar, Scientific-research. Journal of Shahed University, 19(98), 73-83.

Shakeri, M., Fekri, S. H., \& Shahnavaz, A. (2012).The Effect of Education Program Based on BASNEF Model On physical Activity of Pregnant Women. Journal of Urmia Nursing And Midwifery Faculty, 6(41), 832-840.

Sharma, M., \& Romas, J. A. (2008). Theoretical foundations of health education and health promotion. Sudbury, jones and arlett publishers..

Skaal, L., \& Pengpid, S. (2012). The predictive validity and effects of using the transtheoretical model to increase the physical activity of healthcare workers in a public hospital in South Africa. Transl Behav Med, 2(4), 384-391 http://dx. doi.org/ 10.1007/s13142-012-0136-5

Soleiman Ekhtiari, Y., Shojaeizadeh, D., Rahimi Foroushani, A., Ghofranipour, F., \& Ahmadi, B. (2013). The Effect of an Intervention Based on the PRECEDE- PROCEED Model on Preventive Behaviors of Domestic Violence Among Iranian High School Girls. Iran Red Crescent Med J, 15(1), 21-28. http://dx. doi.org/10.5812/ircmj.3517 
Solhi, M., Motlagh, F. Z., Shirazi, K. K., Taghdisi, M. H., \& Jalilian, F. (2012). Designing and Implementing Educational Programs to Promote Physical Activity Among Students: An Application of the Theory of Planned Behavior. Ofogh-e-danesh. Journal of Gonabad University of Medical Sciences and Health Services, 18(1), 45-52.

Solhi, M., Ahmadi, L., Taghdisi, M. H., \& Haghan, H.(2011). The Effect of Trans Theoretical Model (TTM) on Exercise Behavior in Pregnant Women Referred to Dehaghan Rural Health Center. Iranian Journal of Medical Education, 11(8), 942-950.

Strijk, J. E., Proper, K. I., van Mechelen, W., \& van der Beek, A. J. (2013). Effectiveness of a worksite lifestyle intervention on vitality, work engagement, productivity, and sick leave: results of a randomized controlled trial. Scand J Work Environ Health, 39(1), 66-75. http://www.sjweh.fi/show_abstract.php?abstract_id=3311

Tabatabaei, S. V. A., Taghdisi, M. H., Sadeghi, A., \& Nakhaei, N. (2010). The effect of education in physical activities on knowledge, attitude and behavior of Kerman health center\&\#8217;s staff. Journal of Research \& Health(Social Development \& Health Promotion Research Center), 2(1), 55-62.

Timori, P., Esmailnasab, N. (2011). Application of Health PromotionModel In Study Of Physical Activity Of Sanandaj students. Journal of School of Public Health and Institute of Public Health Research, 9(1), 35-46.

Timori, P., Niknami, S. H., \& Ghofranipour, F. (2007). Effects of a School-Based Intervention on the Basis of Pender's Health Promotion Model to Improve Physical Activity among High School Girls. Armaghane-danesh. Journal of Yasuj University of Medical Sciences, 12(2), 47-59.

Tyler, I., Rowlands, M., \& Spasoff, R. (2009). An Environmental Scan of Best Practices in Public Health Undergraduate Medical Education. Public Health Agency of Canada.

Van Wier, M. F., Ariens, G. A., Dekkers, J. C., Hendriksen, I. J., Pronk, N. P., Smid, T., \& van Mechelen, W. (2006). ALIFE@Work: a randomised controlled trial of a distance counselling lifestyle programme for weight control among an overweight working population [ISRCTN04265725]. BMC Public Health, 6, 140. http://dx. doi.org/10.1186/1471-2458-6-140

World Health Organization. (2013). Physical activity. Retrieved from http://www.who.int/Health topics/physical activity/factsheet

World Health Organization. (2012). Health education: theoretical concepts, effective strategies and core competencies: a foundation document to guide capacity development of health educators. Regional Office for the Eastern Mediterranean, Cairo

World Health Organization. (2010). Global Recommendations on Physical Activity for Health. Retrieved from http://www.who.int/Health topics/physical activity/publications.

\section{Notes}

Note 1 : $\mathrm{N}=$ Number, $\%=$ Percent.

Note 2: N/A: not available.

\section{Copyrights}

Copyright for this article is retained by the author(s), with first publication rights granted to the journal.

This is an open-access article distributed under the terms and conditions of the Creative Commons Attribution license (http://creativecommons.org/licenses/by/3.0/). 